\title{
PELATIHAN AKUNTANSI DAPAT MENINGKATKAN KINERJA WIRAUSAHA
}

\author{
${ }^{1}$ Satiman, ${ }^{2}$ Suparmin, ${ }^{3}$ Edon Ramdani, ${ }^{4}$ Maharani, dan ${ }^{5}$ Rahma Wiyanti \\ ${ }^{1}$ satiman@estika.co.id ${ }^{2}$ dosen01601@unpam.ac.id ${ }^{3}$ edon_ramdani@yahoo.com ${ }^{4}$ dosen01758@unpam.ac.id \\ ${ }^{5}$ wiyan_zal@yahoo.com \\ ${ }^{12345}$ Prodi S-1 Akuntansi Fakultas Ekonomi Universitas Pamulang, Banten
}

\begin{abstract}
Abstrak
Tujuan pengabdian kepada masyarakat ini ialah untuk memberikan pelatihan akuntansi kepada anak-anak binaan Yayasan Al-Kamilah berupa pembuatan laporan keuangan, perhitungan BEP, dll sehingga mereka semangat dalam mendirikan usaha mandiri. Metode pengabdian kepada masyarakat ini ialah pelatihan, seminar, dan diskusi. Populasi dalam kegiatan pengabdian kepada masyarakat ini ialah sebanyak 100 anak yang merupakan binaan Yayasan Al-Kamilah Pamulang Hasil dari pengabdian kepada masyarakat ini ialah seluruh peserta dapat menerapkan teori akuntansi dalam usahanya
\end{abstract}

Kata Kunci : Pelatihan Akuntansi, Wirausaha

\section{Abstract}

The purpose of this community service is to provide accounting training for the children of the Al-Kamilah Foundation in the form of financial reporting, BEP calculations, etc. so that they are enthusiastic in establishing an independent business. The method of community service is training, seminars, and discussions. The population in this community service activity is 100 children who are under the auspices of the Al-Kamilah Pamulang Foundation. The result of this community service is that all participants can apply accounting theory in their efforts.

Keywords: Accounting Training, Entrepreneurship

\section{PENDAHULUAN}

Manusia di dunia mempunyai kehidupan saling tolong menolong kepada sesamanya. Manusia dalam menjalankan aktivitasnya baik di dalam keluarga, dalam masyarakat, dalam lembaga, tidak dapat berhasil tanpa kerja sama, tolong menolong. Nabi Muhammad S.A.W. bersabda "Barangsiapa menolong saudaranya, maka Allah akan selalu menolongnya". (HR. Bukhari dan
Muslim). Ajaran Nabi Muhammad S.A.W mengajarkan kepada ummatnya untuk saling membantu saudaranya, terutama membantu yang lemah, hidupnya di bawah garis kemiskinan. Mereka yang keadaannya demikian itu di antaranya adalah anak-anak terlantar yang seharusnya dipelihara oleh negara dan menjadi tanggung jawab moral bersama sebagai warga masyarakat Indonesia. 
Yayasan Al Kamilah, Serua Raya RT 03/05 Kelurahan Serua Kecamatan Bojongsari Kota Depok Jawa Barat, terdiri 7 (tujuh) orang pengurus, yang telah menyelesaikan pendidikan sarjana dan pascasarjana. Mereka terpanggil menjalankan perintah ajaran agama yang diyakininya yaitu agama Islam. Dalam ajaran Islam diajarkan bagi yang telah mampu membatu orang-orang yang lemah tidak menunggu setelah mempunyai hartabenda yang berlimpah akan tetapi menyisihkan sebagian rezeqi yang telah didapatnya untuk diberikan kepada yang berhak menerimanya. Dan 23 Orang anak asuh yang sedang proses pendidikan pada tingkat Sekolah Dasar hingga tingkat Sekolah Lanjutan Tingkat Atas, yang sangat membutuhkan biaya pendidikan, sandang dan pangan yang jumlahnya tidak sedikit. Mereka memerlukan bantuan seraca moril dan materiil. Anak-anak asuh Yayasan Al Kamilah berasal dari kalangan yang tidak mampu akan tetapi mereka luar biasa. Mereka semangat dalam belajar tinggi, mereka mempunyai kegiatan rutin baik dari pendidikan formal maupun non formal.

Kami sebagai Dosen Akuntansi S1 Fakultas Ekonomi Universitas Pamulang UNPAM merasa terpanggil, sehingga kami melaksanakan Pengabdian Kepada Masyakarat di sekitar UNPAM dengan cara memberikan binaan pada anak-anak asuh
Yayasan Al Kamilah, dengan cara memberikan materi dengan judul "Akuntansi Dapat Meningkatkan Kinerja Wirausaha", sehingga kelak nanti anakanak dimaksud memiliki bekal untuk mengembangkan bakat mereka.

\section{METODE}

\section{Populasi.}

Populasi dalam pengabdian kepada masyarakat ini ialah sebanyak 100 orang yang merupakan anak binaan Yayasan AlKamilah Pamulang.

\section{Metode Kegiatan.}

Metode kegiatan pengabdian kepada masyarakat ini, antara lain :

\section{Seminar.}

Seminar adalah adalah pertemuan untuk membahas suatu masalah yang dilakukan secara ilmiah. Pada seminar biasanya menampilkan satu atau beberapa pembicaraan dengan makalah atau kertas kerja yang sebelumnya telah di persiapkan. Seminar ini bertemakan perencanaan keuangan, dan penerapan etika bisnis.

\section{Diskusi.}

Diskusi adalah suatu interaksi komunikasi yang terjadi antara dua orang atau secara berkelompok di mana tujuannya untuk membahas suatu tema atau 
topik tertentu sehingga menghasilkan suatu kesepakatan pendapat. Diskusi dilakukan oleh pemateri dengan peserta sehingga para peserta dapat menerapkan materi yang disampaikan dalam menjalankan bisnisnya.

\section{HASIL DAN PEMBAHASAN}

\section{Pengaruh Pelatihan Akuntansi}

\section{Terhadap Kinerja Berwirausaha.}

Setelah mengikuti kegiatan pengabdian kepada masyarakat ini, seluruh peserta yang tergabung dalam anak binaan Yayasan Al-Kamilah dapat melakukan perencanan keuangan antara lain: menghitung seluruh biaya produksi, menghitung biaya pemasaran produk dan jasa, meminimalisir resiko bisnisnya, dan dapat mengetahui keuntungan yang ingin dicapai dalam periode tertentu dengan cara menetapkan harga produk dan jasa yang ingin dijual sehingga mereka tetap bermotivasi dalam pengembangan usahanya.

\section{Pengaruh Pelatihan Akuntansi} Terhadap Kinerja Yayasan Al-Kamilah.

Setelah mengikuti kegiatan pengabdian kepada masyarakat ini, seluruh peserta yang tergabung dalam anak binaan Yayasan Al-Kamilah dapat melakukan cara investasi yang menguntungkan seperti : memilih objek investasi yang memberikan keuntungan di masa mendatang, memilih objek investasi yang dapat memberikan return dalam jangka waktu cepat, dan mengetahui cara pengamanan aset sehingga mereka tetap bermotivasi dalam pengembangan usahanya.

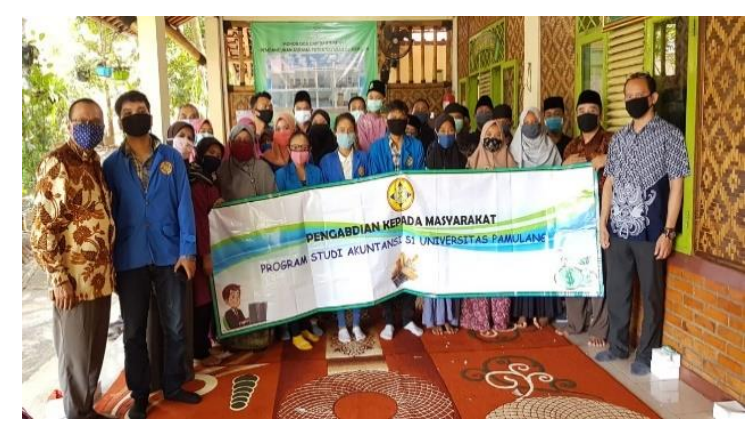

Gambar I. Para Peserta PKM

\section{KESIMPULAN}

1. Pelatihan akuntansi berpengaruh terhadap kinerja berwirausaha di Yayasan Al-Kamilah. Hal ini ditandai dengan anak binaan Yayasan Al-Kamilah dapat melakukan perencanan keuangan antara lain: menghitung seluruh biaya produksi, menghitung biaya pemasaran produk dan jasa, meminimalisir resiko bisnisnya, dan dapat mengetahui keuntungan yang ingin dicapai dalam periode tertentu dengan cara menetapkan harga produk dan jasa yang ingin dijual sehingga mereka tetap bermotivasi dalam pengembangan usahanya.

2. Pelatihan akuntansi berpengaruh terhadap kinerja di Yayasan Al- 
Kamilah. Hal ini ditandai dengan Yayasan Al-Kamilah dapat melakukan cara investasi yang menguntungkan seperti: memilih objek investasi yang memberikan keuntungan di masa mendatang, memilih objek investasi yang dapat memberikan return dalam jangka waktu cepat, dan mengetahui cara pengamanan aset sehingga mereka tetap bermotivasi dalam pengembangan usahanya.

\section{REFERENSI}

Agoes, Sukrisno. (2012). Etika Bisnis dan Profesi. Jakarta: Salemba Empat.

Danim, Sudarwan, (2012). Inovasi Pendidikan dalam Upaya Peningkatan Profesionalisme Tenaga Kependidikan. Bandung: CV Pustaka Setia.

Exposure Draft Standar Akuntansi Keuangan Entitas Mikro Kecil Menengah (SAK- EMKM). (2016). IAI:Jakarta Selatan.

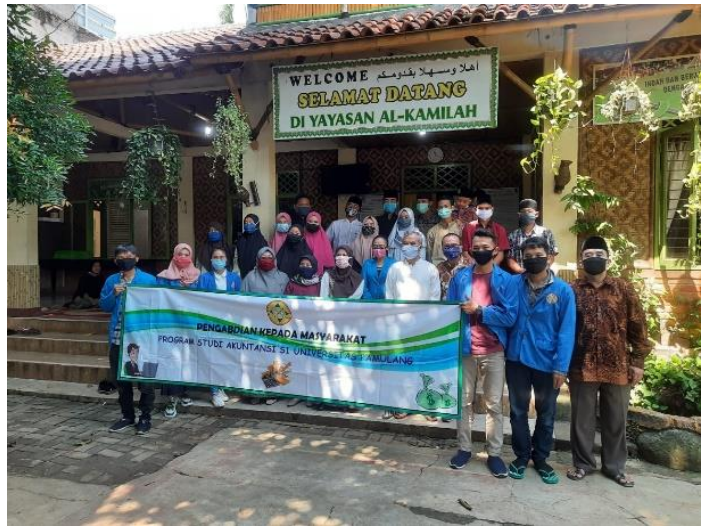

Gambar II. Pelaksanaan PKM di

Yayasan Al-Kamilah

Ikatan Akuntansi Indonesia atau PSAK (2007).

Pedoman Teknis Pencatatan Transaksi Keuangan Usaha Kecil Badan

Usaha Bukan Badan Hukum

Sektor Perdagangan. (2015). Bank

Indonesia: Jakarta.

Yani, Afrida dkk. (2020). Perancangan Siklus Akuntansi Pada Bank Sampah. Abdimisi Vol. 1 No. 1 Desember. 